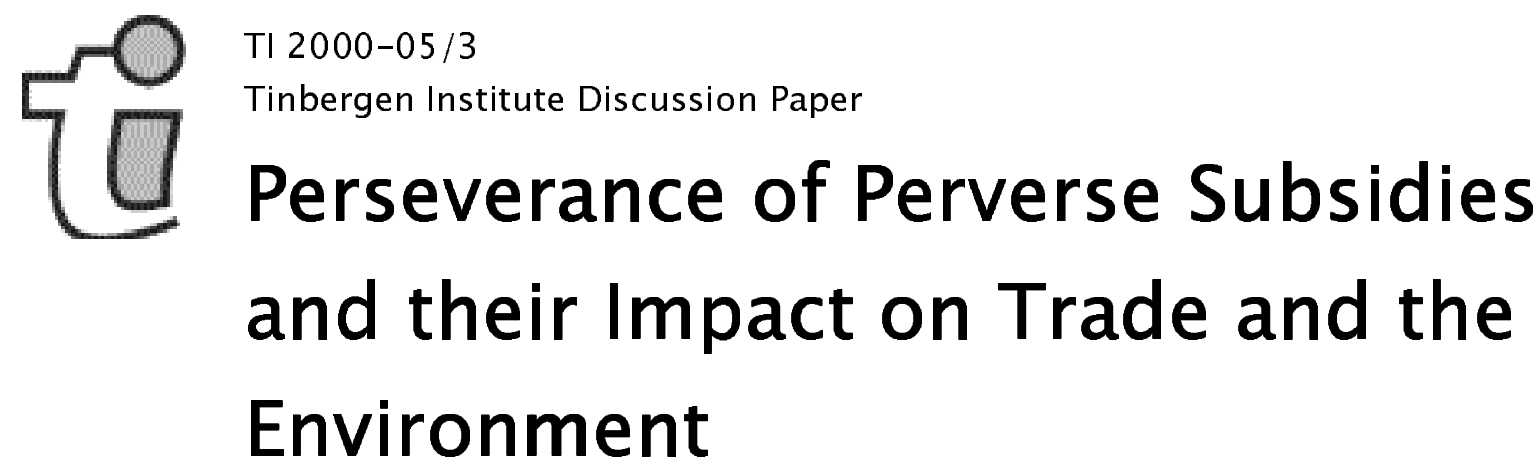

Cees van Beers'

Jeroen C.J.M. van den Bergh²

' Department of Economics, Delft University of Technology,

2 Department of Spatial Economics, Faculty of Economics and Econometrics, Vrije Universiteit Amsterdam and Tinbergen Institute 


\section{Tinbergen Institute}

The Tinbergen Institute is the institute for economic research of the Erasmus Universiteit Rotterdam, Universiteit van Amsterdam and Vrije Universiteit Amsterdam.

\section{Tinbergen Institute Amsterdam}

Keizersgracht 482

1017 EG Amsterdam

The Netherlands

Tel.: $\quad+31 .(0) 20.5513500$

Fax: $\quad+31 .(0) 20.5513555$

\section{Tinbergen Institute Rotterdam}

Burg. Oudlaan 50

3062 PA Rotterdam

The Netherlands

Tel.: $\quad+31 .(0) 10.4088900$

Fax: $\quad+31 .(0) 10.4089031$

For a list of other recent TI discussion papers, please see the back pages of this paper.

TI discussion papers can be downloaded at

http: / / www.tinbergen.nl 


\title{
Perseverance of Perverse Subsidies and their Impact on Trade and the Environment
}

\author{
Cees van Beers \\ Department of Economics \\ Delft University of Technology \\ P.O. Box 5050 \\ 2600 GB Delft \\ vanbeers@wtm.tudelft.nl \\ and \\ Jeroen C.J.M. van den Bergh \\ Department of Spatial Economics \\ Free University \\ De Boelelaan 1105 \\ 1081 HV Amsterdam \\ jbergh@econ.vu.nl
}




\begin{abstract}
The role of subsidies has largely been neglected in the literature on environmental policy and international trade. This article draws the attention to theoretical and empirical aspects of policy failures resulting from subsidies. Examples of subsidies that cause environmental externalities are discussed in the context of a general classification. The economic and environmental impacts of producer subsidies in an international setting are examined with theoretical partial equilibrium analyses. An empirical assessment of the magnitude and economic and environmental relevance of subsidies in various sectors is presented. Finally, suggestions are provided on how subsidy-related policy failures can be eliminated at national and international levels. This is a requirement to reach a situation of international harmonization of environmental regulation.
\end{abstract}

\title{
Keywords
}

Environmental policy; Trade policy; Perverse subsidies; International institutions; International agreements. 


\section{Introduction}

In the past fifteen years many studies have appeared on the potential conflict between free trade and environmental regulation, the impact of environmental regulation on international trade flows and locations of firms, and the use of trade measures in environmental policy. Both international and environmental economists have contributed to these issues (for an overview, see van Beers and van den Bergh 1996). A theme that is largely missing from this literature is policy failures operating at an international level. The existence of such failures suggests that proposals for environmental policy reform will often be incomplete or too lax, and that progress in moving toward desired environmental policies is overestimated. The reason is that through policy failures governments contribute to the level of external costs imposed upon current society and future generations. As a consequence, optimal or good environmental policies do not only require the implementation of additional policy instruments, but also, or especially, the removal of existing policies. The latter explains why progress in environmental policy, both at national and international levels, has turned out to be so difficult: it has been hampered by existing institutions and policies that are often vigorously supported by vested interests of various stakeholders.

Apart from the static inefficiency of this situation, the persistence of various policy and institutional failures during many decades has created a situation of 'lock-in' of existing economic and institutional structures. At an international level this 'lock-in' is supported and reinforced by policy failures that have distorted comparative advantage patterns and thus the international distribution of economic activities. This has affected all aspects of specialization patterns: location of firms, foreign investments (by multinationals and investment funds), and international trade. Moreover, the existence of policy failures has turned out to create a severe obstacle to progress in international trade negotiations, thus reinforcing the 'lock-in'.

Subsidies have been, and still are, an important category of policy failures on the international level. They have created a complex system of distortionary impacts on international markets of primary, intermediate and final goods. An important characteristic of environmentally damaging subsidies (EDS), often referred to as 'perverse subsidies', is their concealment or 'hidden' character. This has two reasons. First, indirect effects of subsidies contribute to the invisibility of their total impact. For example, various subsidies influence the relative costs of alternative energy and mineral resources, of production techniques of export goods, and of international transport modes. Second, many EDS are implicit subsidies, or are for other reasons often not considered or recognized as subsidies. An example is the existence of payment arrears in the Russian Federation (van Beers and de Moor, 1998, p. 15). A careful analysis is required to reveal the environmentally damaging character of many (hidden) subsidies. Whereas taxation of natural resources has been studied for a long time within both environmental and public economics (Baumol and 
Oates 1988; Heaps and Helliwell 1985), subsidies have received hardly any attention. ${ }^{1}$

This article is an attempt to systematically examine the role and importance of subsidies in the trade-environment-policy triangle. This will involve addressing a mix of theoretical and empirical questions: Which effects of subsidies on quantities produced and consumed, and on measurement of environmental indicators, can be expected in theory? What is the empirical magnitude of market distortions and environmental impacts caused by subsidies? How should policy failures due to subsidies be corrected and prevented? What is the role of the hidden character of many subsidies in creating barriers against removing policy failures? And how can specific institutions, such as the World Trade Organization (WTO), contribute to the elimination of policy failures at an international level?

The article is organized as follows. Section 2 presents a range of classifications of subsidies. Section 3 discusses the issue of EDS in a standard partial equilibrium framework applied to closed and open economies, as well as to perfect and imperfect competition. Section 4 gives a concise overview of the empirical magnitude of subsidies in various economic sectors, along with their international and environmental implications. Section 5 offers some proposals to eliminate or reform environmentally damaging subsidies and devotes attention to the role of national and international solutions. A final section presents conclusions.

\section{A typology of environmentally damaging subsidies}

Subsidies are implemented for various reasons:

- as an instrument of environmental policy, e.g. to stimulate the production of less pollutive goods and services;

- to provide for cheap production factors, notably energy resources;

- to stimulate investments and technological development (R\&D);

- as an instrument of labor market policy, notably for creating or maintaining employment; and,

- as an instrument of trade policy, for instance, to stimulate the export of goods that is domestically produced at prices above world market price levels.

OECD (1996) defines subsidies as comprising all measures that keep prices for consumers below market level or for producers above market level, or that reduce costs for consumers and producers by giving direct or indirect price support. ${ }^{2}$

Many types of subsidies exist, serving many different purposes. Export subsidies, for instance, are aimed at supporting export sectors. Subsidies can stimulate environmental damage. Environmentally damaging subsidies should not be confused with subsidies as

\footnotetext{
${ }^{1}$ A rare analytical study addressing on-budget subsidies is Parry and Bento (1999).

${ }^{2}$ Most notorious are the export subsidies on agricultural products in the European Union.
} 
instruments of environmental policy. The latter are used to attain environmental goals without generating costs on individual firms or households, and are an alternative to charges, taxes and standards as instruments of environmental policy. Environmentally damaging subsidies are commonly applied with a non-environmental policy goal, and have unintentional environmental impacts.

A general classification of subsidies can start with a distinction between producer and consumer subsidies (de Moor and Calamai 1997). Following the OECD-definition on Producer Subsidy Equivalents (PSE), producer subsidies are defined as all price measures and associated transfers of income that increase the income of the producer. Consumer subsidies are defined, according to the Consumer Subsidy Equivalents (CSE), as all price measures and associated transfers of money that increase the income of the consumer (see OECD 1997). A further distinction is into on-budget and off-budget subsidies (de Moor and Calamai 1997). On-budget subsidies are all expenditures and associated transfers of money that have an impact on the government budget, for instance, a tax cut. Off-budget subsidies are government interventions that do not affect the government budget but do change net financial assets and liabilities. An example is a government's prescription that a private company supplies a commodity against a price below the market price.

Table 1. A typology of subsidies

\begin{tabular}{|c|c|c|c|c|}
\hline \multirow[t]{2}{*}{ Type of intervention } & \multicolumn{2}{|c|}{ Consumer subsidies } & \multicolumn{2}{|c|}{ Producer subsidies } \\
\hline & On-budget & Off-budget & On-budget & Off-budget \\
\hline $\begin{array}{l}\text { Budgetary money } \\
\text { handouts }\end{array}$ & $X$ & & $X$ & \\
\hline Capital costs subsidies & & & $X$ & \\
\hline $\begin{array}{l}\text { Public provision of } \\
\text { goods and services } \\
\text { below cost price }\end{array}$ & & $X$ & & $X$ \\
\hline $\begin{array}{l}\text { Policies creating } \\
\text { transfers through the } \\
\text { market }\end{array}$ & $X$ & $X$ & $X$ & $\mathrm{X}$ \\
\hline Regulations & & $X$ & & $X$ \\
\hline Price subsidies & $\mathrm{X}$ & $\mathrm{X}$ & $X$ & $X$ \\
\hline Export subsidies & & & $X$ & \\
\hline
\end{tabular}

Table 1 has been arranged according to the method of transfer. It shows that consumer and producer subsidies come in various types. In other words, subsidies are not uniform and will therefore not always be recognized as such. Moreover, subsidies are not restricted to concrete financial support (a certain amount of money) provided by the 
government to a particular consumer or producer. They also include transfers through the tax system and different types of off-budget subsidies, such as soft loans and regulations like minimum prices and local purchase obligations. Especially government regulations do not necessarily provide a direct cost for the government although they can do so for society as a whole.

Consumer subsidies dominate in developing countries. Due to a lack of tax revenues it is often impossible to provide on-budget subsidies to consumers. Hence, strict price regulation, to keep consumer prices below unrestricted market prices, is the only way to prevent the exclusion of low-income consumers from buying basic goods like drinking water, energy carriers, and food.

In developed countries producer subsidies are quite common. Subsidies to production imply a transfer of resources from consumers (off budget) or taxpayers (on budget) to producers, for instance, by guaranteeing minimum prices above market level. Producer subsidies affect the resource end of the chain of economic processes and usually have more far-reaching implications than consumer-subsidies at the final-goods end of the chain. Hence, producer subsidies are generally more significant from the perspective of eliminating environmentally damaging subsidies. Producer subsidies can be further distinguished into input and output subsidies. Input subsidies are aimed at reducing the costs of raw materials, capital goods or labor. Output subsidies are meant to reduce the supply price of the commodity produced. A subdivision of these latter two categories is shown in Table 2.

Table 2. Input and output oriented producer subsidies

\begin{tabular}{lll}
\hline Type of intervention & Input oriented & Output oriented \\
\hline $\begin{array}{l}\text { Capital cost subsidies } \\
\quad \text { loan guarantees, debt }\end{array}$ & $\mathrm{X}$ & \\
$\quad$ forgiveness) & & \\
Tax deductible allowances & $\mathrm{X}$ & \\
Public provision below cost & $\mathrm{X}$ & \\
$\quad$ price (e.g. infrastructure, & & \\
energy) & & $\mathrm{X}$ \\
Purchase obligations & $\mathrm{X}$ & $\mathrm{X}$ \\
Minimum prices & & $\mathrm{X}$ \\
Export subsidies & $\mathrm{X}$ & \\
Import taxes & & \\
\hline
\end{tabular}

A special feature of many environmentally damaging subsidies is their hidden character. Whereas money transfers relating to on-budget subsidies are visible in the government 
budget, the indirect channels through which they increase environmental damage are hard to detect empirically. Moreover, in the case of off-budget subsidies the magnitude of subsidies remains unclear. Recent studies indicate that at a global scale hidden environmentally damaging subsidies have a very large negative environmental impact (de Moor and Calamai, 1997; Myers, 1998; van Beers and de Moor, 1999a and b).

\section{Theoretical implications of producer subsidies in an international context}

\subsection{Subsidies in general}

Government policies in a market economy affect the prices of private goods and services. If prices and quantities demanded and supplied would be optimal, i.e. if prices would incorporate the marginal external costs of negative effects on the natural environment, government interventions through subsidies would lead to prices and quantities that encourage environmental degradation and hence are sub-optimal. If in addition external effects are not optimally priced environmental damage will even be greater. The general direct effect of a subsidy is a price reduction of a commodity. If a subsidy is handed out directly to the consumer that buys a particular good, consumption increases as the demand price falls. A direct on-budget subsidy given to a profit-maximizing producer generates an increase in the quantity supplied as his marginal costs decrease. This increase is highest when competition is perfect and lowest in case of a pure monopoly supplier.

Not all subsidies are bad simply because the effects they generate on consumption and production go along with negative environmental impacts. The usefulness of subsidies depends on their contribution to the intended goal that has to be weighted against their unintended and undesirable impact on the natural environment (and directly and indirectly human health and welfare). In practice it is very hard to assess this trade-off. As a first step to a proper judgement EDS will be discussed in theoretical partial equilibrium models for a closed economy. Subsequently, EDS will be considered in open economy situations with perfect and imperfect competition.

\subsection{Subsidies in a closed economy with perfect competition}

This section focuses on producer subsidies, as these are dominant in most developed countries and have the most severe and indirect impact on environmental degradation (de Moor and Calamai, 1997). The fact that environmentally damaging subsidies are often concealed and have detrimental effects on the environment frustrates environmental policies. Figure 1 shows the impact of environmental policies in the presence of environmentally damaging subsidies. 


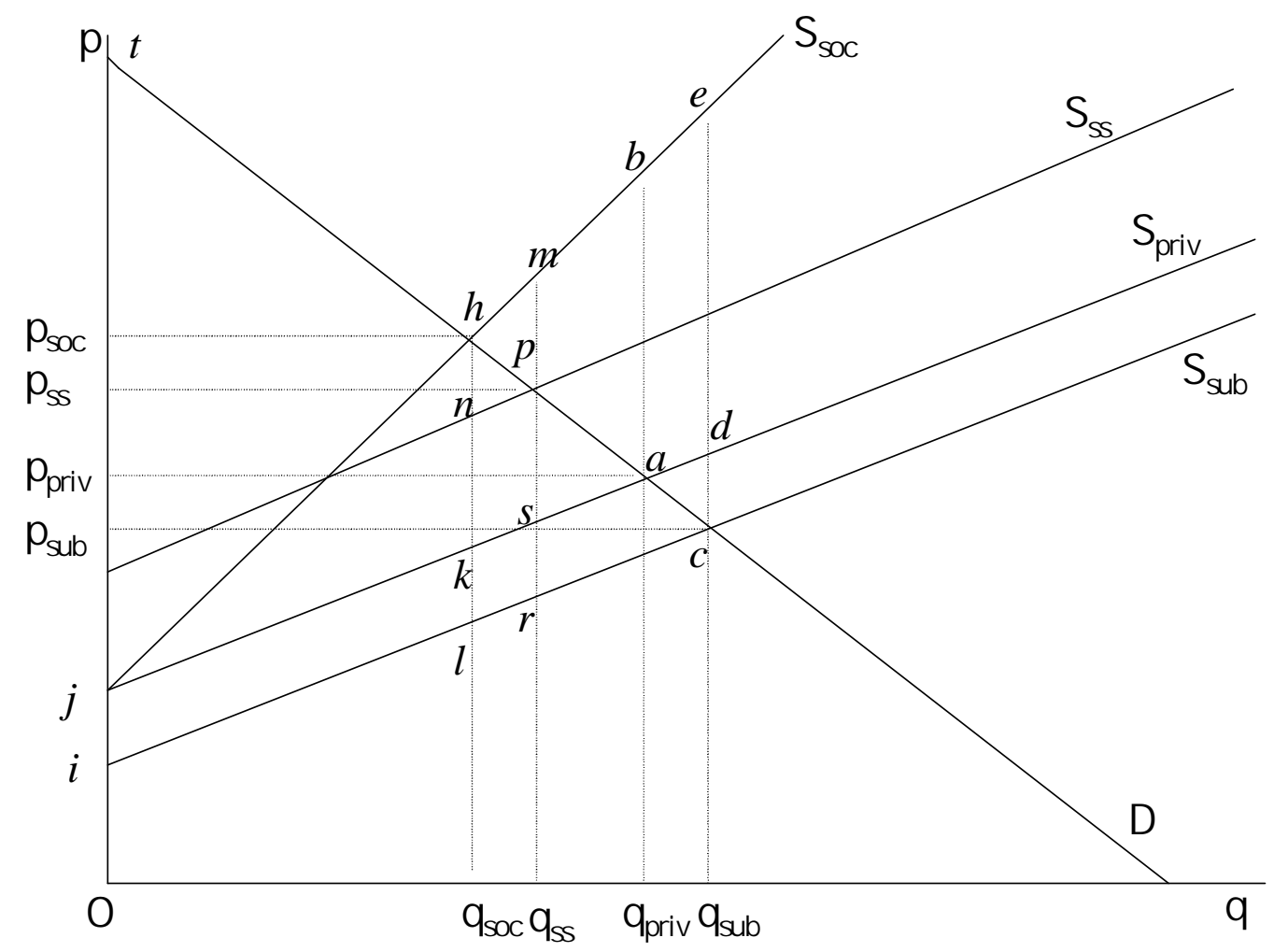

Legend:

$\mathrm{q} \quad$ = quantity;

$\mathrm{p} \quad=$ price;

$\mathrm{D} \quad=$ demand curve;

$\mathrm{S} \quad=$ supply or marginal cost curves;

$\mathrm{S}_{\mathrm{sub}} \quad=$ supply curve based on real private production costs distorted by hidden EDS;

$\mathrm{S}_{\text {priv }} \quad=$ supply curve based on real private production costs;

$\mathrm{S}_{\mathrm{ss}} \quad$ = supply curve based on real social costs of production distorted by hidden EDS;

$\mathrm{S}_{\mathrm{soc}} \quad=$ supply curve based on real social costs of production.

Figure 1. Inefficient pollution levels as a result from hidden producer EDS in a closed economy: perfect competition

Figure 1 shows a standard partial equilibrium diagram with demand and supply curves under perfect competition in a closed economy. Point $a$ denotes the equilibrium situation that results when private production costs include neither subsidies nor externality taxes. In this case the amount of $\mathrm{q}_{\text {priv }}$ is produced. The marginal external effect generated at this production level is equal to $a b$, i.e. the distance between the marginal private costs curve $\mathrm{S}_{\text {priv }}$ and the marginal social cost (= private + external cost) curve $\mathrm{S}_{\mathrm{soc}}$. The total external cost is equal to the area $b a j$. Total welfare is $h j t-b a h$. A Pigouvian tax equal to $k h$, i.e. the distance between the private cost curve and social cost curve at quantity $\mathrm{q}_{\mathrm{soc}}$, i.e. at the intersection of the demand and social cost curves, would generate the socially optimal equilibrium. Total welfare is then hjt, which is larger than the level of welfare in the equilibrium without environmental policy. The welfare gain is $b a h=b a k h-a k h$. Here 
$b a k h$ is the reduction of external costs, while the triangle $a k h$ is the deadweight loss (i.e. the loss of consumer and producer surplus), both resulting from the Pigouvian tax. ${ }^{3}$

Assume for simplicity that a constant subsidy equal to $j-i$ independent of the level of production is provided. This shifts the supply curve $S_{\text {priv }}$ downward to $S_{\text {sub }}$ and increases the level of production output that clears the market to $\mathrm{q}_{\text {sub }}$. The marginal social cost produced at this level of production is ce, i.e. the sum of the social cost due to the subsidy $(c d)$ and the externality cost $(d e)$. Total welfare is equal to the area $h j t-e c h$, which is smaller than total welfare at the private optimum with externalities but without a subsidy.

When the subsidy is 'hidden', the policy-maker may incorrectly regard $S_{\text {sub }}$ as the real private production costs and $\mathrm{q}_{\text {sub }}$ as the quantity based on real private production costs. This means that $\mathrm{s} /$ he confuses point $c$ with point $a$. Moreover, in this case $k h$, i.e. the distance between $S_{\text {soc }}$ and $S_{\text {priv }}$ will mistakenly be regarded as the tax level needed to reduce the externality to its socially optimal level. However, a tax $k h$ imposed on $S_{\text {sub }}$, instead of $\mathrm{S}_{\text {priv }}$, implies that the quantity produced will be reduced to $\mathrm{q}_{\mathrm{ss}}$, which is higher than the optimal quantity produced $\mathrm{q}_{\mathrm{soc}}$. This result is obtained by drawing a line $\mathrm{S}_{\mathrm{ss}}$ parallel to $\mathrm{S}_{\text {sub }}$ through point $n$, which is located at a distance $j$-i (i.e. $l k=n h$ ) below point $h$ at $\mathrm{q}_{\mathrm{soc}}$, so that the distance $k h$ is equal to the distance $r p$. Under this incorrect environmental policy the subsidy creates an extra external cost, i.e. above the optimal level, equal to $m s j-h k j=$ $m s k h$. In addition, the subsidy causes a direct public cost of provision equal to srij. Total welfare in a situation of incorrect environmental policy due to EDS is thus equal to $h j t-$ $m p h{ }^{4}$ If $m p h<a b h$ a situation with EDS and environmental policy would be preferable over a situation without both EDS and environmental policy. This is possible when the subsidy is not too large.

\subsection{Subsidies in an open economy with perfect competition}

EDS also disturb optimal trade patterns. In Figure 2 the effect of EDS in a small exporting economy is presented. This represents a situation where the price of the commodity in the world market, $\mathrm{p}_{\mathrm{w}}$, is given and higher than the price in the domestic market, $\mathrm{p}_{\mathrm{dom}}$, so that the country will export the commodity. In the absence of environmental policy and EDS $\mathrm{q}_{\text {priv }}$ is the quantity produced, of which $\mathrm{q}_{\mathrm{dw}}$ serves domestic demand and the remainder, $\mathrm{q}_{\text {priv }}$ $-\mathrm{q}_{\mathrm{dw}}(b d)$, foreign demand. In this equilibrium total welfare of the exporting country is equal to $r j t-e d b r$. The component $e d b r$ is the difference between $e d s r$, i.e. the total external cost due to a lack of optimal environmental policy, and the consumer and producer surplus $d s r b$ associated with producing more than the socially optimal quantity (of which

\footnotetext{
${ }^{3}$ Parry and Bento (1999) call this triangle the primary cost of policy.

${ }^{4}$ The provision costs, srij, have not been subtracted from $h j t-m p h$ in this partial equilibrium framework. Provision costs are not necessarily equal to their welfare effect. This depends on the benefits they generate through public expenditures. In the present partial equilibrium analysis the net effect is assumed to be zero to keep things simple. A general equilibrium analysis is needed to shed more light on this issue.
} 
$\mathrm{q}_{\mathrm{dw}}-\mathrm{q}_{\mathrm{soc}}$ meets domestic demand and $\mathrm{q}_{\mathrm{priv}}-\mathrm{q}_{\mathrm{dw}}$ foreign demand).

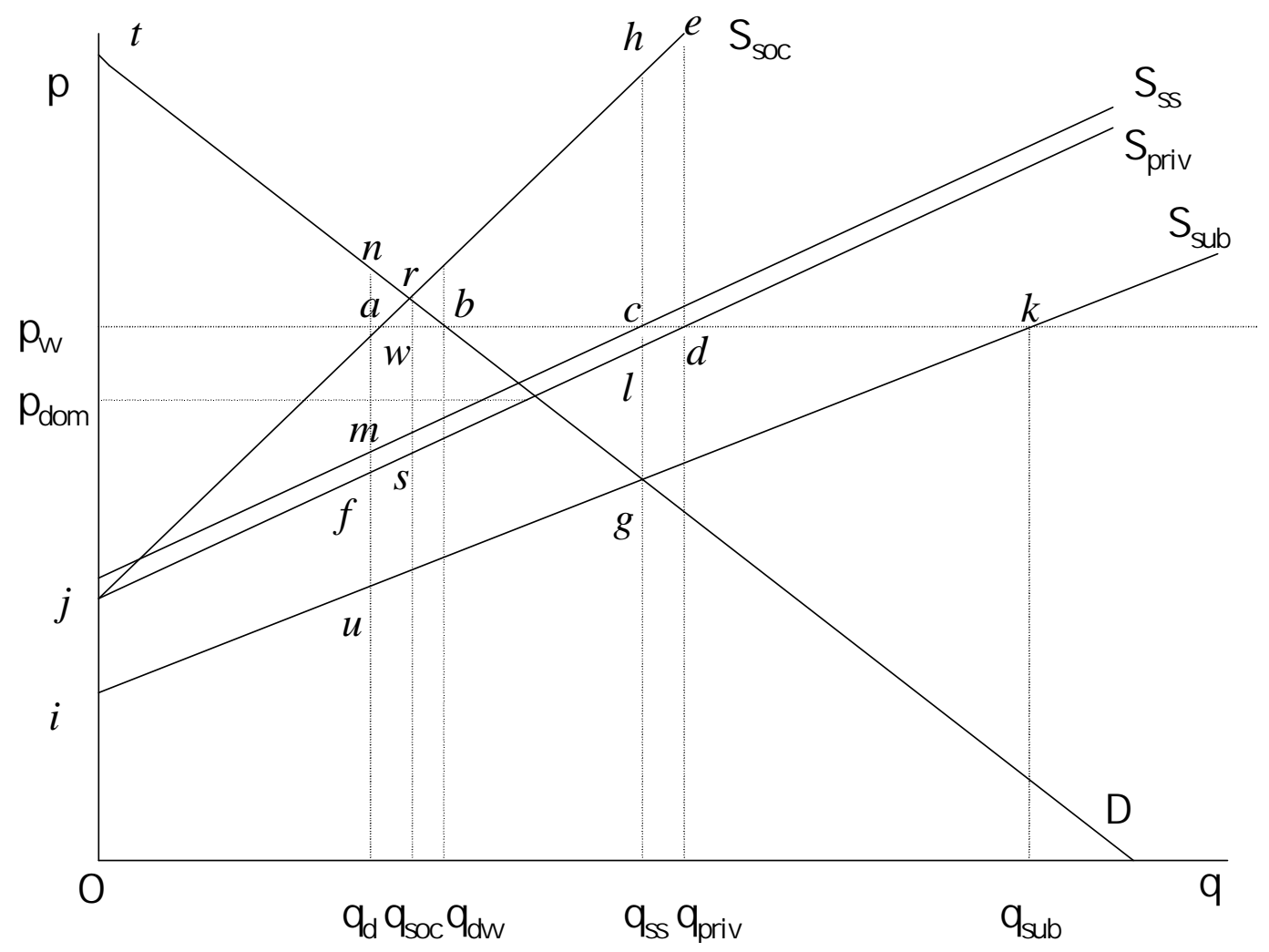

Legend:

$\mathrm{q} \quad$ = quantity;

$\mathrm{p} \quad$ = price;

$\mathrm{p}_{\mathrm{w}} \quad=$ world market price;

$\mathrm{p}_{\mathrm{dom}}=$ domestic market price;

$\mathrm{D} \quad=$ demand curve;

$\mathrm{S} \quad=$ supply or marginal cost curve;

$\mathrm{S}_{\mathrm{sub}} \quad=$ supply curve based on real private production costs distorted by hidden EDS;

$\mathrm{S}_{\text {priv }} \quad=$ supply curve based on real private production costs;

$\mathrm{S}_{\mathrm{ss}} \quad=$ supply curve based on real social costs of production distorted by hidden EDS;

$\mathrm{S}_{\mathrm{soc}} \quad=$ supply curve based on real social costs of production

Figure 2. Inefficient pollution levels due to hidden EDS in an exporting economy: perfect competition

In a closed economy the Pigouvian tax $s r$ would induce the socially optimal equilibrium $\mathrm{q}_{\mathrm{soc}}$, with total welfare equal to rjt. In this open economy, however, the optimal tax is equal to $f a$, inducing the domestic production level $\mathrm{q}_{\mathrm{d}}$ (i.e. the intersection of 
$\mathrm{S}_{\mathrm{soc}}$ and $\mathrm{p}_{\mathrm{w}}$ ), and giving rise to imports equal to $\mathrm{q}_{\mathrm{dw}}-\mathrm{q}_{\mathrm{d}}(a b) .{ }^{5}$ The case depicted in Figure 2 shows that the implementation of an optimal environmental policy in the open economy would be able to turn an exporting into an importing country. Welfare in the social optimum equals najt + ban $(=r t j+b a r)$; here najt is the consumer and producer surplus of domestically produced goods, and ban the consumer surplus of imports.

Consider now the situation with EDS. Then exports are higher, and equal to $\mathrm{q}_{\mathrm{sub}}-$ $\mathrm{q}_{\mathrm{dw}}(b k)$. If the subsidy is 'hidden', a policy maker observes $\mathrm{q}_{\text {sub }}-\mathrm{q}_{\mathrm{dw}}$ but thinks this is $\mathrm{q}_{\text {priv }}$ $-\mathrm{q}_{\mathrm{dw}}$. Moreover, a tax $f a$ is no longer optimal, as it will induce domestic production to be equal to $\mathrm{q}_{\mathrm{ss}}$ (in order to see this note that the distance $i j=u f=m a$, so that $f a=g c$ ). Instead of the optimal situation with imports a situation with exports results, with exports equal to $\mathrm{q}_{\mathrm{ss}}-\mathrm{q}_{\mathrm{dw}}(b c)$. Total welfare in this case is equal to najt + ran $-h c b r(=t r j-h c b r)$. The area $(r a n+h c b r)$ is equal to the area $h l f a$, the external cost due to incorrect environmental policy, minus the area $c l f n b$, i.e. the sum of consumer and producer surplus associated with production $\mathrm{q}_{\mathrm{ss}}-\mathrm{q}_{\mathrm{d}}$. The area lgij is the public cost of providing the EDS.

Note that in all previous cases domestic demand is unaffected by the combinations of tax and subsidy, as the commodity is traded against a fixed world price $\mathrm{p}_{\mathrm{w}}$.

\subsection{Subsidies in an open economy with imperfect competition}

Figure 3 shows the effects of various combinations of tax and subsidy in an international setting when competition is imperfect. In particular, assume that the firm is a monopolist in the domestic market but meets perfect competition in the world market. The case described hereafter is an extension of the imperfect competition case considered in van Beers and van den Bergh (1996).

In a situation without EDS and environmental policy the monopolist produces $\mathrm{q}_{\mathrm{dom}}$ (the intersection of the marginal revenue (MR) and $S_{\text {priv }}$ curves) for the domestic market, sold against price $\mathrm{p}_{\mathrm{dom}}$. Exports are equal to $\mathrm{q}_{\text {priv }}-\mathrm{q}_{\mathrm{dom}}(n d)$. Compared with the case of perfect competition in the domestic market, the monopolist can charge a higher price reducing domestic demand to such an extent that extra supply to the world market is generated. This means that profits from both domestic and foreign sales is higher than under perfect competition. Welfare in this world, without EDS and environmental policy, is equal to twnaj - eda.

A Pigouvian tax equal to the distance $f a$ induces production to be equal to $\mathrm{q}_{\mathrm{soc}}$. In contrast with the case of perfect competition discussed above, the price of domestic supply is now affected by environmental policy. It becomes $\mathrm{p}_{\text {dom, }}{ }_{\text {, which induces a domestic }}$ demand equal to $\mathrm{q}_{\text {dom. }}^{\prime}$. Exports are then equal to $\mathrm{q}_{\mathrm{soc}}-\mathrm{q}_{\text {dom. }}^{\prime}$. Note that the monopolist reduces its domestic supply below the social optimum (intersection of $S_{\mathrm{soc}}$ and D). Total welfare under the tax $f a$ is tlmaj.

In the presence of hidden EDS and a tax $f a$ (implying the $\mathrm{S}_{\mathrm{ss}}$ curve) domestic

\footnotetext{
${ }^{5}$ It is assumed that domestic and foreign markets are not segmented.
} 
supply is q" dom and exports are $\mathrm{q}_{\mathrm{ss}}-\mathrm{q}$ " ${ }_{\text {dom }}(u c)$. This creates an external effect equal to $h g f a$. Welfare now is tpuaj-hca. The public cost of providing the subsidy is equal to gxij, which can be quite large.

Note that the assumption of a monopolistic supplier on the domestic market makes only sense in a situation with exports. When, due to the position of the curves or the implementation of a subsidy or tax, imports are the outcome, the assumption of a monopolist no longer holds. The reason is that in this case multiple suppliers exist on the domestic markets, which implies an oligopolistic or perfectly competitive market.

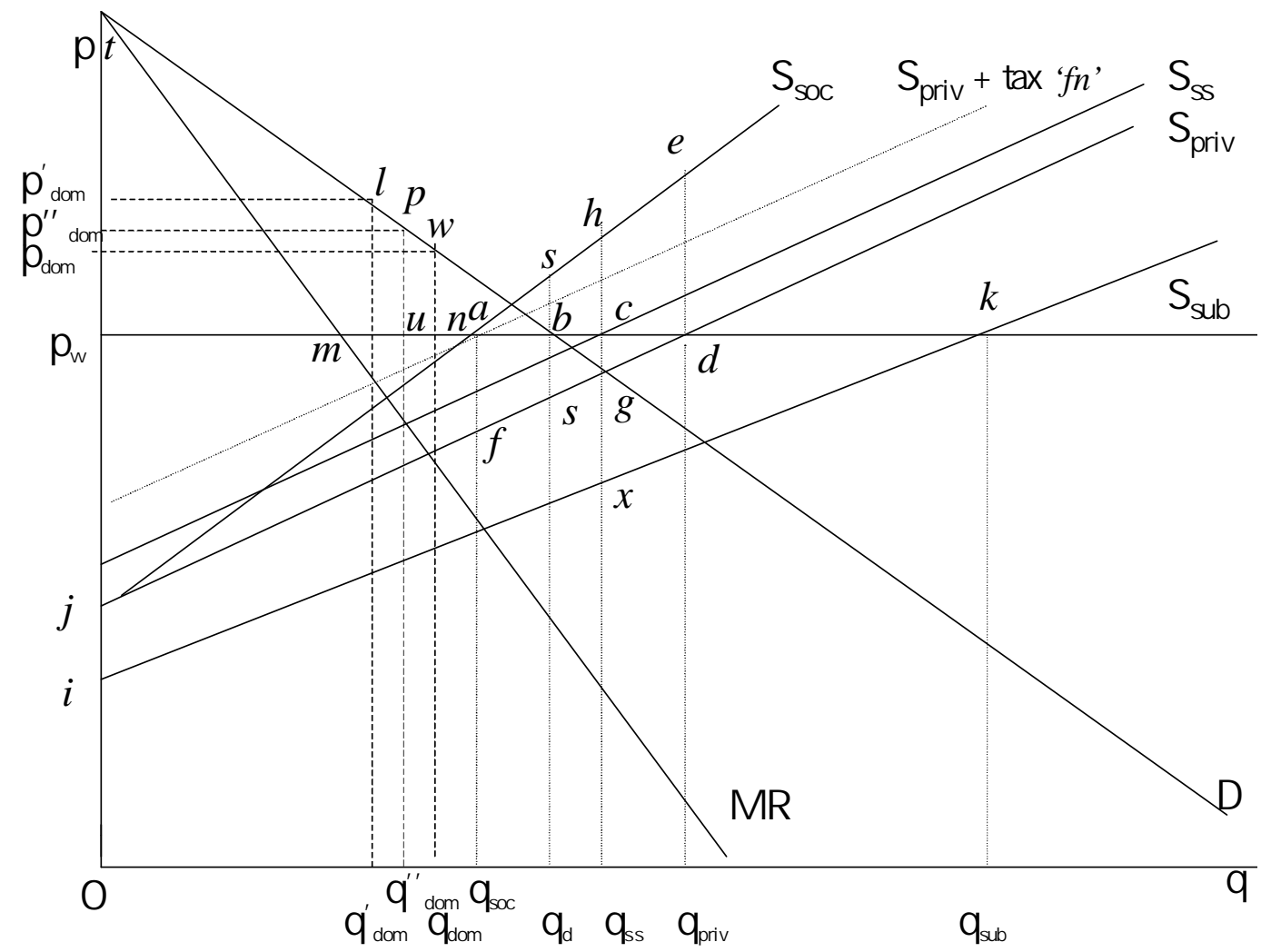

Legend:

$\mathrm{q} \quad$ = quantity;

$\mathrm{p} \quad=$ price;

$\mathrm{p}_{\mathrm{w}} \quad=$ world market price;

$\mathrm{q}_{\mathrm{dom}} \quad=$ quantity produced for domestic market;

$\mathrm{D} \quad=$ demand curve;

$\mathrm{S} \quad=$ marginal cost curve;

$\mathrm{S}_{\mathrm{sub}} \quad=$ marginal costs based on real private production costs distorted by hidden EDS;

$\mathrm{S}_{\text {priv }} \quad=$ marginal costs based on real private production costs;

$\mathrm{S}_{\mathrm{ss}} \quad=$ marginal costs based on real social costs of production distorted by hidden EDS;

$\mathrm{S}_{\mathrm{soc}} \quad=$ marginal costs based on real social costs of production

Figure 3. Inefficient pollution levels due to hidden EDS in an exporting economy: imperfect competition 


\subsection{Distribution and dynamic issues}

Subsidies have additional effects on production and consumption. In the first place, subsidies have distribution impacts as they imply a money transfer from taxpayers to a group that directly benefits from the subsidy, and worse even, from the victims to the polluters. This means that subsidies require budgetary policies. For instance, the budget requirement can be uncertain due to the fact that the level of subsidies depends on the size of the market. Moreover, the taxes needed to create the funds for subsidies have distortionary effects on other markets than the one directly subsidized. These welfare costs have not even been considered in the above partial equilibrium analyses. Subsidies also have dynamic impacts: they stimulate certain investments, they create certain type of growth patterns, and they enforce a certain historical development ('path dependence'). This makes subsidies - paying polluters to reduce pollution - less attractive for environmental policy than taxes, in spite of the fact that less public control is needed since polluters will be happy to report information required for receiving the subsidy. The dynamic impacts of subsidies imply that the negative effects of EDS illustrated by the foregoing theoretical analyses will be reinforced over time.

\section{Environmental damaging subsidies and international trade: empirical observations}

Recent empirical evidence shows that environmentally damaging subsidies merit further attention only because of their sheer magnitude (see van Beers and de Moor 1999a; Myers 1998, de Moor and Calamai 1997; OECD 1998 and 1997a). World wide, governments are heavily engaged in providing subsidies. The costs associated with public support policies are huge. Table 3 shows that a rough estimate of the costs of global subsidies is $\$ 950$ billion a year or 3.6 per cent of global GDP. The table also gives an indication of the potential magnitude of the impact of subsidies in particular sectors on world trade flows and the natural environment.

Three observations can be made. Firstly, the three sectors receiving most of the subsidies (81.5\% of global subsidies) affect $66.1 \%$ of total world trade. If manufacturing is added, $87.3 \%$ of subsidies affects $96.7 \%$ of world trade. This, together with the theoretical insights of the previous section, indicates that subsidies have potentially a strong effect on world trade flows. Secondly, certain environmental problems, in particular the emission of greenhouse gases, the contribution to acid rain, and water pollution, are strongly affected by the sectors receiving most of the subsidies and making up a substantial part of world trade. In other words, eliminating EDS may be essential for arriving at structural solutions to such environmental problems. Thirdly, transport receives many subsidies, which implies that the impact on international trade of subsidies provided to the other sectors is even underestimated, given that international trade of physical commodities 
is heavily dependent on transport. In fact, this means that physical trade flows are doubly stimulated by subsidies.

Table 3. Indicators of impact of subsidies on trade and environment

\begin{tabular}{|c|c|c|c|}
\hline Sector & $\begin{array}{l}\text { Cost of subsidies } \\
\text { (in billion US\$; } \\
\text { percentage of total } \\
\text { global subsidies in } \\
\text { parentheses) }\end{array}$ & $\begin{array}{l}\text { Trade flows } \\
\text { (percentage of } \\
\text { world trade) }\end{array}$ & $\begin{array}{l}\text { Important environmental } \\
\text { effects }\end{array}$ \\
\hline Agriculture/Fisheries & $345(36,3)$ & 15.4 & $\begin{array}{l}\text { Soil erosion } \\
\text { Contribution to acid rain } \\
\text { Depletion fish stock } \\
\text { Extinction of species } \\
\text { Water pollution } \\
\text { Aquaculture }\end{array}$ \\
\hline Transport & $225 \quad(23,7)$ & 43,2 & $\begin{array}{l}\text { Emission greenhouse gases } \\
\text { Contribution to acid } \\
\text { Other air pollution } \\
\text { Noise } \\
\text { Accidents }\end{array}$ \\
\hline Energy & $205 \quad(21,5)$ & 7.5 & $\begin{array}{l}\text { Emission greenhouse gases } \\
\text { Contribution to acid rain } \\
\text { Scarcity of energy resources }\end{array}$ \\
\hline Water & $60 \quad(6,3)$ & NA & $\begin{array}{l}\text { Soil erosion } \\
\text { Water pollution } \\
\text { Water scarcity }\end{array}$ \\
\hline Manufacturing & $55 \quad(5,8)$ & 30.6 & Water and air pollution \\
\hline Forestry & $35 \quad(3,7)$ & 0.4 & $\begin{array}{l}\text { Emission of greenhouse gases } \\
\text { Deforestation } \\
\text { Biodiversity loss }\end{array}$ \\
\hline Mining & $25 \quad(2,6)$ & 1.2 & $\begin{array}{l}\text { Water, soil and air pollution } \\
\text { Scarcity of mineral resources }\end{array}$ \\
\hline Total & 950 & & \\
\hline $\begin{array}{l}\text { Total in \% of World } \\
\text { GDP }\end{array}$ & 3.6 & & \\
\hline
\end{tabular}

Note: 'NA' = not available.

Sources: UN Statistical Yearbook (1997), UN Monthly Bulletin of Statistics (1998), van Beers and de Moor (1999a).

\section{Removing environmentally damaging subsidies in an international context}

The previous two sections suggest that the cost in terms of lost welfare due to EDS is significant. The removal of EDS is necessary but extremely difficult to realize. It involves 
identifying specific problems associated with the elimination of EDS, defining solutions in general terms, and devising politically viable solutions on an international level.

A central characteristic of EDS is that they benefit a limited number of people that experience a reduction of welfare if the subsidies are removed. Such vested interests create much opposition against the elimination of EDS. This phenomenon is explained by the theory of interest groups (Olson 1965). Related to this is rent-seeking behavior aimed at the creation of new subsidies. Rent seeking is a non-productive activity since labor (and capital) is used to obtain a portion of the public budget for no good reason (Krueger, 1974). In addition, there is a more general resistance against the removal of supporting policies like subsidies when they concern old industries that host much employment (e.g., shipping, and agriculture).

Policy solutions to cope with the elimination of these barriers are twofold. On the one hand, governments can assist the groups that will be harmed by the removal of subsidies, namely by offering them (temporary) financial assistance and re-education to adjust to a situation without subsidies. A second solution is more general, namely a removal of subsidies embedded in a larger and fundamental process of deregulation, liberalization and privatization. This can help to create more flexible product and labor markets, so that product innovation is stimulated and labor excess in certain deregulated sectors can be compensated by the growth of other sectors. Particularly the Millenium Round of trade negotiations offers many opportunities to abolish many EDS, notably since environmentalists and free-trade supporters should agree on a number of fundamental issues (although the recent WTO meeting in Seattle suggests otherwise).

National solutions should be aimed at where possible. They come in two types. First, domestic subsidies are to be removed that relate to domestically consumed or produced products. Wolfson (1996) has argued that economic research should focus on identifying the losers and winners of tax and subsidy reform. He suggests directing the reform to the most 'responsive' or 'elastic' parts of the economy. Explicit and implicit subsidies should be focused on. Explicit ones are the easiest perhaps, including various resource extraction and use-related subsidies. They can easily be identified, and the argumentation is straightforward: they distort market prices, and often reinforce environmental externalities. Removal of implicit subsidies requires tax reform at a larger scale than that of particular sectors. This is much more complicated, socially and politically. Nevertheless, it may work via relatively small changes, for instance, by first concentrating political efforts on removing various tax arrangements that act as implicit subsidies and have unambiguous environmental impacts (road taxes and infrastructure provision, VAT exemptions, tax deductions, etc.).

In general, national governments should worry about whether the decisions taken to implement subsidies in the past are still supported by the original arguments. In other words, the original reasons for introducing particular subsidies may no longer hold true. In 
this case an argument additional to the environmental damage stimulation exists in favor of removing the respective subsidies.

The problem seems to be even more complex. Many EDS have been around for quite some time and thus have given rise to a 'lock-in' of certain technologies and activities. This holds with regard to the main sectors receiving support through subsidies, notably energy provision, agriculture and transport. This is also illustrated by the terminology 'addiction to subsidies'. Removal of EDS therefore is associated with enormous sunk costs and costs of moving away from historical paths of development. It is not clear how this problem should be tackled. Trying to realize a slow change seems to make sense (Pearce and Finck von Finckenstein 1999), but may in fact be unsuitable to create sufficient momentum necessary to jump to another development path.

Specific international agreements might focus on EDS removal. However, integration of the goal to remove subsidies internationally with existing environmental and trade agreements seems to stand a better chance. The World Trade Organization (WTO) could act as a starting point, as it already addresses the link between trade and subsidies. The principle of non-discrimination, the core of the WTO rules, consists of the Most Favored Nations (MFN) and the National Treatment (NT) clauses (art. I/III). MFN requires that imports of 'like' (or: similar) products from different exporting countries meet identical trade barriers; NT means that imported products are not allowed to be subjected to more strict taxation and regulation than similar products produced domestically. One focal point of future trade negotiations should be the sharpening of the NT-clause. The present clause allows the favoring of foreign production and investment by providing subsidies that stimulate foreign investments with negative environmental impacts. National Treatment might be replaced by a Principle of International Treatment (PIT), stating that foreign investments cannot be favored over domestic investments. The PIT should be defined in such a way that elements like the level of development, the quality of the natural environment, existing trade and environmental impacts of foreign direct investments are fully taken into account.

Finally, other institutions at an international level can be used to help remove subsidies, notably the IMF and the World Bank, which can include subsidy-related conditions in the provision of loans to countries. The IMF would be most suitable to cover the national policy level and the World Bank the regional and local policy levels.

\section{Conclusions}

Subsidies have usually been implemented with certain objectives. The problem is that these objectives have changed over time, and that a subsidy is bound to have unintended and often unforeseen effects. If such effects include significant environmental damage then we refer to environmentally damaging subsidies. Subsidies lead to prices that convey fundamentally incorrect information about real costs, relating to production, extraction or 
resource scarcity. Subsidies run the risk of favoring less profitable over more profitable firms, if profitability includes social costs. Subsidies should never be structural, and only be used to guide transition periods. Otherwise they will make firms dependent and weak through structurally misdirecting their cost-effectiveness and innovation strategies.

Subsidies have a tremendous impact on the international trade system. This has been illustrated by partial equilibrium analyses, which show that a situation of exports with subsidies can even change in a situation with imports when existing subsidies are removed. Moreover, in an international context subsidies can stimulate production far beyond a socially optimal level, thus contributing significantly to an excess of negative welfare effects.

Empirical indicators suggest that there is a close relationship between subsidies to particular sectors and the contribution of these sectors to international trade. The most important sectors in this respect are agriculture, transport, and manufacturing. Transport subsidies reinforce the impact on trade of subsidies to other sectors. The most important categories of environmental issues affected by EDS are the emission of greenhouse gases, acid rain and water pollution. Credible solutions to these problems require the removal of EDS.

Eliminating perverse subsidies runs against various barriers. On a national level vested interest, distribution issues, costs of structural change, and 'lock-in' play an important role. These all translate to political barriers, which are magnified by the international context. In particular, governments are worried about the impact of removing subsidies on the competitive position of particular sectors. In addition, policy changes are severely restricted by the guidelines and barriers following from international agreements and institutions, such as the EU, the IMF, the World Bank, and the GATT/WTO. Important steps in stimulating the removal of subsidies include: quantifying the extent of implicit and explicit subsidies; revisiting the original motivations for implementing subsidies; providing information to the public about the costs of EDS (or the benefits of removing them); testing existing subsidies for consistency with GATT regulations; devoting attention to implicit subsidies in revising tax systems; providing national and local conditions relating to subsidies, notably by international organizations like the IMF and World Bank to developing countries; and providing transitional support and assistance to sectors harmed by the removal of EDS.

\section{References}

Anderson, K. and R. Blackhurst, 1992. The Greening of World Trade Issues. Harvester Wheatsheaf, New York.

Baumol, W.J. and W.E. Oates, 1988. The Theory of Environmental Policy. 2nd ed. Cambridge University Press, Cambridge, UK.

van Beers, C. and J. van den Bergh, 1996. An Overview of methodological approaches in the analysis of trade and environment. Journal of World Trade 30: 143 - 167. 
Reprinted in: A.M. Rugman, J.J. Kirton en J.A. Soloway (eds.), 1998. Trade and Environment: Economic, Legal and Policy Perspectives. Edward Elgar, Cheltenham. van Beers, C. and A. de Moor, 1998a, Scanning subsidies and policy trends in Europe and Central Asia, Environmental Information and Assessment Technical Report, No. 2, UNEP, Nairobi.

van Beers, C. and A. de Moor, 1998b, Perverse subsidies, International Trade and the Environment, Plaejamento E Politicas Publicas, special issue on environmental policy, Instituto de Pesquisa Economica Aplicada, December, p. 49-68.

van Beers, C. and A. de Moor, 1999. Addicted to subsidies, IOO Working paper 95, Institute for Research on Public Expenditure, The Hague.

Heaps, T., and J.F. Helliwell, 1985. The taxation of natural resources. In: A.J. Auerbach and M. Feldstein (eds.). Handbook of Public Economics. Elsevier Science Publishers, Amsterdam.

Krueger, A.O., 1974, The political economy of a rent seeking society, American Economic Review, 64, pp. 291-303.

Low, P., 1992. International Trade and Environment. World Bank Discussion Papers, 159, World Bank, Washington D.C.

de Moor, A. and P. Calamai, 1997. Subsidizing unsustainable development: undermining the Earth with public funds. IOO bv/the Earth Council.

Myers, N., 1998. Perverse Subsidies. International Institute for Sustainable Development. Canada.

OECD, 1996, Subsidies and Environment. Exploring the Linkages, OECD, Paris.

OECD, 1997a. Reforming Energy and Transport Subsidies. OECD, Paris.

OECD, 1997b. Agricultural Policies in OECD Countries. Monitoring and Evaluation, Paris.

OECD, 1998. Improving the Environment through Reducing Subsidies, Part I: Summary and Policy Conclusions. OECD, Paris.

Olson, M., 1965. The Logic of Collective Action. Harvard University press, Cambridge, MA.

Parry, I.W.H., and A.M. Bento, 1999, Tax deductions, Environmental Policy, and the “Double Dividend” Hypothesis, World Bank Policy Research Working Paper 2119, forthcoming in Journal of Environmental Economics and Management.

Pearce, D. and D. Finck von Finckenstein, 1999, "Advancing Subsidy Reforms: Towards a Viable Policy Package", Paper prepared for the Fifth Expert Group Meeting on Financial Issues of Agenda 21, Nairobi, 1999.

UN Monthly Bulletin of Statistics (1998), vol. 52, no. 5, United Nations, New York.

UN Statistical Yearbook (1997). issue 42, United Nations, New York.

Wolfson, D., 1996. Tax differentiation, subsidies and the environment. In: OECD, Subsidies and the Environment: Exploring the Linkages. OECD, Paris. 
The World Bank, 1992. World Development Report 1992. Washington, D.C. 